\author{
AN INTERNATIONAL JOURNAL OF ARTS AND HUMANITIES \\ (IJAH) \\ Bahir Dar, Ethiopia \\ Vol. 3 (3), S/No 11, July, 2014: 178-194 \\ ISSN: 2225-8590 (Print) ISSN 2227-5452 (Online) \\ DOI: http://dx.doi.org/10.4314/ijah.v3i3.13
}

\title{
DOES ABSOLUTE SYNONYMY EXIST IN OWERE-IGBO?
}

\author{
OMEGO, CHRISTIE U. \\ Department of Linguistics and Communication Studies \\ University of Port Harcourt \\ Port Harcourt, Rivers State, Nigeria \\ Tel: +2348033504741 \\ E-mail: omegochristie @ yahoo.com
}

\begin{abstract}
Among Igbo linguistic researchers, determining whether absolute synonymy exists in Owere-Igbo, a dialect of the Igbo language predominantly spoken by the people of Owerri, Imo State, Nigeria, has become a thorny issue. While some linguistic scholars strive to establish that absolute synonymy exists in the lexical structure of natural language, others invest much vigorous effort to debunk the claim. This researcher, therefore, conducted an empirical research to provide a factual clue to the question of whether absolute synonymy exists in the lexical structure of OwereIgbo or otherwise. With 200 copies of questionnaire administered and retrieved from 200 Research Collaborators, who are also fluent native speakers, the research was conducted. The researcher also interviewed native speakers of the dialect. The study found out that in each pair of synonyms investigated slight, but detectable differences were always invariably present. This conclusion was drawn based on the observation that synonyms in Owere-Igbo cannot substitute for each other in all contexts, i.e. set of lexemes can substitute for each other in one context, but in another context they
\end{abstract}


cannot substitute without a change in meaning.. This researcher employed various tests such as substitution or interchangeability method, contrastive method and statistical method to test for absolute synonymy in Owere-Igbo. An examination of all illustrative samples of possible candidates for absolute synonymy given by OwereIgbo speakers revealed that none of the pairs of synonymous lexeme investigated satisfied the criteria used.

Key words: absolute synonymy, partial synonymy, lexemes, lexical structure, language

\section{Introduction}

The word 'synonymy' means sameness of meaning, i.e., a relationship in which more than one lexeme have the same meaning or alternatively the same meaning being expressed by more than one lexeme. This definition, as Crystal (1995:164) observes, sounds straight-forward enough, but he cautions that the notion of synonymy is rather curious. The question, according to Crystal, is "why should a language have more than one lexeme to express a particular meaning?" One lexeme per meaning ought to be sufficient. Kreidler (1998:96) agrees with Crystal (1995:164) that synonymy is not a simple matter, for two lexemes never have the same range of syntactic occurrences, and referring expressions. In other words, synonyms are likely to differ in what they suggest. In this study, an attempt is made to ascertain whether absolute synonymy exists in Owere-Igbo or not.

\section{Statement of the Problem}

Facts about human language reveal that there are quite a number of lexemes which are synonymous only in particular contexts, not in all. This explains why a distinction is often made in the literature between absolute or total synonymy and broad or partial synonymy. Some semanticists, however, claim that absolute synonyms exist in natural language (see Ndimele 1999), but argue that it is rare to find. Lyons (1981), also, observed that 'there are few, if any real synonyms in natural language', while Jackson (1988) stressed that absolute synonymy is a luxury that languages can afford to do without. Thus, the problem of establishing whether absolute synonymy exists in natural language which has been a nagging one in general linguistic study necessitated this study. This research, therefore, set out to find solution to the problem of establishing whether absolute synonymy exists in Owere-Igbo, in particular.

\section{Purpose of the Study}

The main purpose of carrying out this study is to ascertain whether absolute synonymy exists in Owere-Igbo. Other objectives of the study are: 
1. to find out whether there are lexemes in Owere-Igbo that are synonymous;

2. to ascertain whether there are ways in which synonymous lexemes differ in Owere-Igbo, and

3. to find out whether there are synonymous lexemes that can substitute for each other in all contexts in Owere-Igbo?

\section{Scope of the Study}

The content of this study covers only synonymy in Owere-Igbo. The study is necessarily restricted to only synonymy which is a lexical semantic relation at word level because we are interested in only lexical semantics. Geographically, the scope covers only five villages of Owerri, the capital city of Imo State, Nigeria where Owere-Igbo is spoken.

\section{Significance of the Study}

For researchers on the semantic structure of Owere-Igbo to properly characterize the lexical structure of the language, it is imperative to establish whether absolute synonymy exists in the language or its dialects. Without that, the characterization of the entire lexical structure might fall short of the required standard. To fill this vacuum is the major aim of this research work. The researcher, therefore, conducted an empirical survey, the outcome of which is expected to clear the controversy on whether absolute synonymy exists in Owere-Igbo or not. The study will also be a contribution to the study of lexical semantics in general linguistic study and to Igboid semantics in particular. Igbo lexicographers, dialectologists and those learning Igbo as a second language will also benefit from this study.

\section{Literature Review}

The term "synonymy" is derived from two Greek words syn meaning 'same' and nymy which means 'name'( Jackson, 1988: 64). Therefore, synonymy is a semantic relation at word-level used to refer to sameness of meaning. Jackson also argued that two words which are totally synonymous is a luxury which a language can afford to do without. The economy of the language, according to him, will not tolerate, except perhaps, for a short period of time, the existence of two words with exactly the same range of contexts of use; and it certainly will not tolerate a proliferation of them. According to Jackson, argument against absolute synonymy is historical. Jackson contended that if absolute synonymy occurs in the language, whether by borrowing or for some other reason, then one of two things tends to happen. Nutsukpo (1992:34) similarly noted that all synonyms are not truly synonymous. This view lends support 
to the views expressed by many other semanticists that absolute synonyms are very rare to find in natural language.

Cruse (1986) proposed a scale of synonymy and argued that since the point of semantic identity, i.e. absolute synonymy is well-defined and the other end-point, the notion of zero synonymy, is far more diffuse, a scale of semantic difference is more satisfactory. This definition of absolute synonymy, according to Cruse (1986), gives the following: Two lexical units would be absolute synonyms if and only if all their contextual relations were identical. He concluded by stating that if absolute synonyms exist, they are extremely rare. Cruse also pointed out that it is only in technical domains that one can find absolute synonyms. For example, Bovine Spongiform Encephalopathy (BSE), and mad cow disease are two names for the same thing. Synonymy has also been defined as identity of all three basic components of meaning: designatum, connotation, and range of application. The term designatum refers to a referent of a single word in the extra linguistic world. Synonyms should have agreement in designatum, Connotation in the definition refers to the feeling or attitudinal value that a lexical element has that distinguishes it from another. "The term range of application" refers to the fact that certain words are used in certain contexts. We speak of a stipend in connection with a student or researcher, whereas salary is used in connection with teachers and other officials. Hence, according to Palmer (1981:89-91), there are no real synonyms, i.e. no two words have the same referent for the following reasons:

a. Some of the synonyms belong to different dialects of a language. Fall, for instance, is used in the USA for the British equivalence of autumn.

b. The different words used for the same meaning are due to the change in style. Degrees of formality will affect the use of synonyms. For instance, gentleman is more formal than man.

c. Some words can be said to be distinct in their emotive or evaluative meanings, while their cognitive meaning remains the same. The function of such words is to influence attitudes. For example, the words politicianstatesman and the likes.

d. Some words, which are similar in meaning, may differ in their collocational contexts. Thus, 'rancid' collocates with butter and bacon.

e. Some words are regarded as similar by lexicographers and dictionary makers. This is a loose sense of synonymy.

Saeed (2009:65) made essentially the same observation and noted that true or exact synonyms are very rare. He cites the following examples to illustrate this point: 
couch/sofa, boy/lad, lawyer/attorney, and large/big, and noted that there are differences in the meaning of these words.

\section{Methods of Study}

The researcher made use of fluent native speakers of Owere-Igbo as research collaborators. The data for the study was collected using interview schedule as research tool. One hundred and twelve respondents form the population of the study, while a sample size of fifty-four adult speakers was purposively selected for the study.

In order to test our research objectives, three methods were adopted. First, we devised a statistical method that depended on the speakers' personal opinion, evaluation and judgment. We consulted the intuition of these native speakers because native speakers of a language are the primary source of information about meaning (Hurford and Heasley 1983:7). Using this method, our respondents were able to tell intuitively if the pairs of lexemes under consideration are absolute synonyms or not. Such evaluation on the part of native speakers served as an investigative procedure in determining absolute synonyms in Owere-Igbo. We further determined the number of speakers that were in agreement and those that disagreed on the absoluteness of the synonyms under investigation. To carry out this test, successfully, we employed simple percentages as our statistical tool. We chose simple percentage because it is more appropriate to use percentages when determining the number of respondents that are in agreement or disagreement with the questions asked about a concept or phenomenon. We must also add that synonymy is more than a statistical matter. It has psychological correlates constituting knowledge that speakers have of their language. It is for this reason that two speakers of Owere-Igbo may disagree on whether some pairs of synonyms are absolute or not. The test we adopted was also intended as a test in the scientific procedure to investigate whether absolute synonymy exist in OwereIgbo as stated in our research objective. The other methods which we adopted in testing for absolute synonymy in Owere-Igbo are the contrastive and the substitution methods.

\section{Data Presentation, Analysis and Discussion of Findings}

The data collected are presented on Tables and descriptively analysed.

Data collected from native speakers of Owere-Igbo indicated that the following lexemes in Owere-Igbo are synonymous: ogologo, egbelegbe and ekwekere, 'tallness'. These lexemes are synonymous because the relationship existing between them is that of oneness (or sameness of meaning). This is diagrammatically shown on 
Fig. 1: Lexemes in Synonymous Relationship:

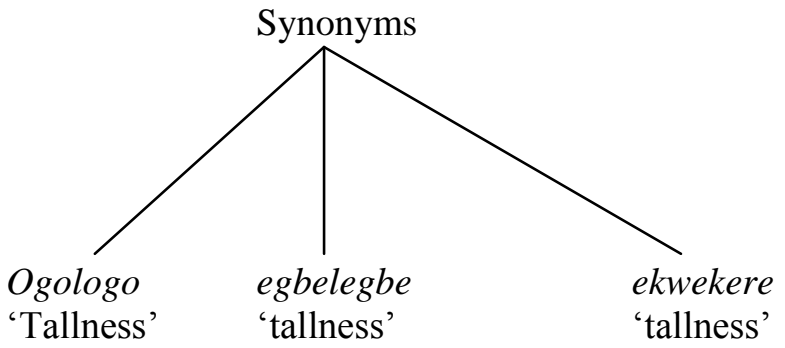

Figure 1 illustrates synonymy which is exemplified by ogologo, egbelegbe and ekwekere, all of which have the same meaning, i.e. 'tallness'. In the same way, Table 1 below contains some other examples of lexemes in synonymous relationship in Owere-Igbo:

Table 1: Synonymous Lexemes in Owere-Igbo

\begin{tabular}{|c|c|c|c|c|}
\hline S/No & Synonyms & Gloss & Matrix (or frame) & English Equivalent \\
\hline 1. & $\begin{array}{l}\text { àbàlì } \\
\text { ùshishì }\end{array}$ & 'night' & 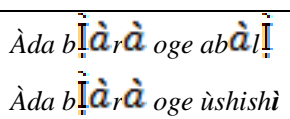 & 'Ada came in the night' \\
\hline 2. & $\begin{array}{l}\text { ahịhịa } \\
\dot{a}_{c h} \grave{a}_{r} \grave{a}\end{array}$ & 'grass' & $\begin{array}{l}\text { Ànyị jè isū ahịhia } \\
\text { Ànyị jè isu } \grave{a}_{c h} \grave{a}_{r} \grave{a}\end{array}$ & 'We are going to cut grasses' \\
\hline 3. & $\begin{array}{l}a k w \grave{a} \\
\text { ǹj }_{j}\end{array}$ & 'cloth' & $\begin{array}{l}A z \text { ừrù̀ } m a k w \grave{a} \\
A z \text { ừrù̀ } m \text { njà }\end{array}$ & 'I bought a piece of cloth' \\
\hline 4. & $\begin{array}{l}\text { àmàmî̃ }_{e} \\
\grave{a}_{k o}\end{array}$ & 'wisdom' & $\begin{array}{l}\text { Udo nwèrè àmàmî̌ } \\
\text { Uddo nwèrềe à } \\
k o\end{array}$ & 'Udo has wisdom' \\
\hline 5. & 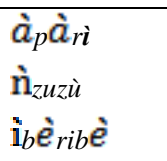 & 'stupidity’ & 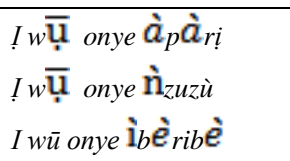 & 'You are a stupid' \\
\hline 6. & $\begin{array}{l}\grave{a}_{l} \grave{a} \\
\text { Ebe }\end{array}$ & 'nativeness' & $\begin{array}{l}O w \overline{\bar{u}} \text { onye } \grave{a ̀}_{l a} \grave{a} \\
O w \overline{\underline{u}} \text { onye }_{e_{b e}} \grave{e}\end{array}$ & 'He is a native of this place' \\
\hline 7. & $\begin{array}{l}\grave{a}_{s h i} \\
\text {ù̀ }_{g h a}\end{array}$ & 'falsity' & 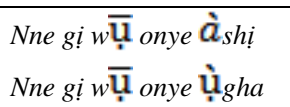 & 'Your mother is a liar' \\
\hline 8. & $\begin{array}{l}\grave{e}_{z h i} \\
\text { òhe }\end{array}$ & 'compound' & $O w \overline{\bar{u}}$ onye èzhi $\bar{\alpha} n y i$ & 'He is from our compound' \\
\hline
\end{tabular}


Does Absolute Synonymy Exist in Owere-Igbo?

\begin{tabular}{|c|c|c|c|c|}
\hline & & & $O w \overline{\underline{u}}$ onye òhe $\bar{\alpha} n y i$ & \\
\hline 9. & $\begin{array}{l}\mathrm{m}_{\text {bara }} \\
\text { obosara }\end{array}$ & 'width' & 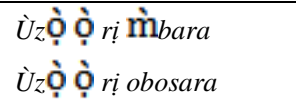 & 'This road is wide' \\
\hline 10. & $\begin{array}{l}\overline{\mathrm{n}}_{n w o} \\
\tilde{\mathrm{h}}_{a}\end{array}$ & $\begin{array}{l}\text { ' } 3^{\text {rd }} \text { pers. pl. pro. } \\
\text { 'their' }\end{array}$ & 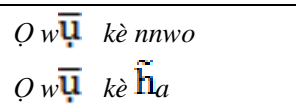 & 'It is theirs' \\
\hline 11. & $\begin{array}{l}m k p o t u \\
\text { ù̀ẓ̌̆ }\end{array}$ & 'noise' & $\begin{array}{l}\text { ńnwo mègà mkpotu } \\
\text { ńnwo mègà ừ zũù }\end{array}$ & 'They are making noise' \\
\hline 12. & $\begin{array}{l}\text { mèshie } \\
g \text { ù̀shie }\end{array}$ & 'close' & $\begin{array}{l}\text { Mèshie uzọ̀ } a h \underline{u ̀ ~} \\
\text { Gùshie uzộ } a h \underline{u}\end{array}$ & 'Close that door' \\
\hline 13. & $\begin{array}{l}g a \\
j e\end{array}$ & 'go' & $\begin{array}{l}G \grave{a}_{a} A b \bar{\alpha} \\
\text { Jèe } A b \bar{\alpha}\end{array}$ & 'Go to Aba!' \\
\hline 14. & $\begin{array}{l}\text { ukwuй } \\
\text { ivù }\end{array}$ & 'big' & $\begin{array}{l}\text { O vu akpa ukwuù ahu } \\
\text { O vu akpa ivù ahu }\end{array}$ & 'He is carrying that big bag' \\
\hline 15. & 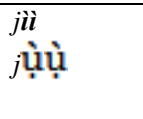 & 'noiselessness' & 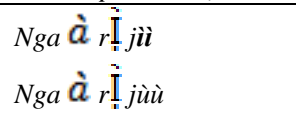 & 'This place is noiseless' \\
\hline 16. & $\begin{array}{l}\text { nway@̣̣̀̆ } \\
\text { nwajìi }\end{array}$ & 'quietness' & 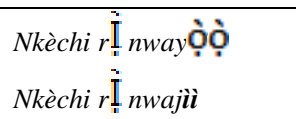 & 'Nkechi is quiet' \\
\hline 17. & $\begin{array}{l}i \tilde{r}_{O} \\
u g w u\end{array}$ & 'enmity' & $\begin{array}{l}I w \overline{\mathrm{u}} \text { onye } i \tilde{r}_{o m} m \\
I w \overline{\mathrm{u}} \text { onye ugwu } m\end{array}$ & 'You are my enemy' \\
\hline 18. & $\begin{array}{l}\text { ngwa ngwa } \\
\text { oso oso } \\
\text { oku oku }\end{array}$ & ‘quickly’ & 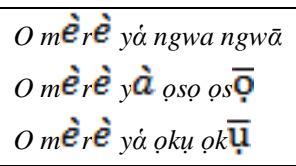 & 'He did it quickly' \\
\hline 19. & $\begin{array}{l}u_{e m e} \tilde{r}_{e} \\
\hat{a}_{g w} \grave{a}\end{array}$ & 'behaviour' & 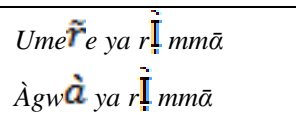 & 'Her behaviour is good' \\
\hline 20. & $\begin{array}{l}\grave{U} s \grave{u} \\
\text { ù̀bì̀ }\end{array}$ & 'poverty' & $\begin{array}{c}O w \overline{\mathrm{u}} \text { onye ùsù } \\
O w \overline{\mathrm{u}} \text { onye ùbị́m }\end{array}$ & 'He is poor person' \\
\hline 21. & $\begin{array}{l}M a \\
s a\end{array}$ & ‘wash' & 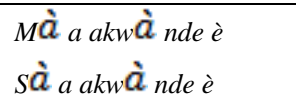 & 'Wash these clothes!' \\
\hline 22. & 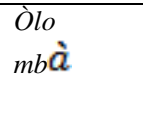 & 'no’ & $\begin{array}{l}A s h \overline{\mathbf{I}} m \text { olò } \\
A s h \overline{\mathbf{I}} m m b \grave{a}\end{array}$ & 'I said no' \\
\hline
\end{tabular}

The sentences contained on Table 1 prove that synonymous lexemes exist in OwereIgbo. These synonyms, as can be observed above, are either nouns as in (1-11), verbs 
as in (12, 13 and 21), adjectives as in (14) or adverbial nouns as in $(15,16$ and 18). A close observation of the sentences also reveals that in each set of synonyms, the synonymous lexemes have the same sense (i.e., there is sameness in meaning). Hence, they are termed synonyms. The question we ask here is whether these lexemes are capable of substituting for each other without altering the meaning of the expression. In other words, does the selection of one lexeme rather than another have any effect on the meaning of the lexeme? Or are there ways in which the meanings of synonymous lexemes differ in Owere-Igbo in certain contexts? This takes us to the next Research objective which is crucial because a look at the synonyms on Table. 1 reveals that there are different ways in which the synonyms can differ. In what follows, we shall analyze the different ways in which synonyms differ, as pointed out by Owere-Igbo speakers with a view to finding out whether absolute synonyms exist or not in the dialect or not. To do this, we shall employ the interchangeability or substitution test.

In applying the interchangeability or substitution test, therefore, we interviewed Owere-Igbo speakers and the majority of them argued that two lexemes which are thought to be synonymous may differ in a number of ways. For example, two lexemes may be synonymous in one context, but have different meaning in another context. Possible factors given as reasons by these respondents include the issue of lexemes having contextual differences, collocative differences, connotative meaning or emotional overtones, etc. These are explained below:

A. Contextual Differences: One of the implications of absolute synonymy is that it must be possible for synonyms to be used interchangeably in all sentence contexts. But our analyses of the sentences above as given by native speakers indicated that there are some sets of lexemes that appear to be synonymous in a particular context, but not in others. The meaning of these sets of synonyms, according to our respondents, is tied up with context. For example, in (7),the pair of lexemes, such as àshi/ụgha 'falsity' are synonymous in some contexts, but not in others. Thus, one can say:

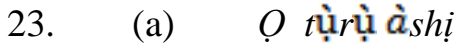

He lie (past) lie

'He lied'

Or

(b) $\quad O$ tù̀rù̀ ù̀ $g h a$

He lie (past) lie

'He lied' 
Or

(c) $O$ ghàrà ựgha

He lie (past) lie

'He lied'

but not

(d) *O ghà rà $\dot{\alpha} s h i ̣$

Table 2 contains more sentence frames to illustrate contexts in which one member of a pair of synonyms may be used and where the other member may not:

Table 2: Synonyms used in Different Contexts

\begin{tabular}{|c|c|c|c|c|}
\hline $\mathbf{S} / \mathbf{N}$ & Synonyms & Gloss & Context $_{1}$ & Context $_{2}$ \\
\hline 34 & $\begin{array}{l}\text { mèshiel } \\
\text { gùshie }\end{array}$ & 'close' & $\begin{array}{l}\text { Mèshie/gùshie uzo ọ̀ } \\
\text { 'close this door' }\end{array}$ & $\begin{array}{l}\text { Mèshie/*gùshie akwukwo ò } \\
\text { 'close this book' }\end{array}$ \\
\hline 35 & ugwu/obo & ‘enmity' & $\begin{array}{l}\text { 'Nnwo nù̀ n'ugwu/obo } \\
\text { 'They are in enmity' }\end{array}$ & $\begin{array}{l}O \text { wu onye ugwu m/*obo } \mathbf{m} \\
\text { 'He is in enmity with me' }\end{array}$ \\
\hline 36 & $u \tilde{z}_{u} / m k p o t u$ & 'noise' & $\begin{array}{l}\text { A nù̀ ga m uzu/mkpotu } \\
\text { 'I am hearing some noise' }\end{array}$ & $\begin{array}{l}\text { Umù̀ nt } \grave{a}_{\text {kirị mèg }} \grave{a} \text { mkpotu/*u} \tilde{z}_{\boldsymbol{u}} \\
\text { 'The children are making niose' }\end{array}$ \\
\hline 37 & $\begin{array}{l}a \tilde{\mathrm{h}}_{\varphi} \tilde{\mathbf{h}}_{u} / \mathrm{ùu}_{b \grave{ }} \\
a_{m}\end{array}$ & 'poverty' & 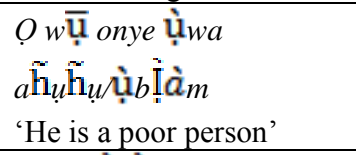 & $\begin{array}{l}O \text { wu onye } \grave{u}_{w a} a \widetilde{\mathrm{h}}_{\varphi} \widetilde{\mathrm{h}}_{u} / * \mathrm{u}_{b} \tilde{I}_{\overline{\mathbf{I}}} \grave{a}_{m} \\
\text { 'He is a poor person' }\end{array}$ \\
\hline 38 & $\hat{n} t \overline{\mathrm{I}} r \mathrm{I} /$ oyi & 'dirtiness' & $\begin{array}{l}\text { I rị ǹt } t \bar{x} r \grave{I} / j u \text { oyi } \\
\text { 'You are dirty' }\end{array}$ & $\begin{array}{l}\text { Uwe gi rị ǹt } \mathbf{I} r \mathrm{I} / * \text { ju oyi } \\
\text { 'Your dress is dirty' }\end{array}$ \\
\hline 39 & $s a / m a$ & 'wash' & $\begin{array}{l}\text { O jiri miri ahù̀ sa/ma uwe } \\
\text { 'He used the water to } \\
\text { wash clothes' }\end{array}$ & $\begin{array}{l}\text { O jèrè miri sa/"ma ahu ya } \\
\text { 'He went to the stream and washed } \\
\text { himself' }\end{array}$ \\
\hline 40 & $\begin{array}{l}\text { ume }{ }^{\tilde{r}} e / \hat{a ̀} g w \\
\grave{a}\end{array}$ & $\begin{array}{l}\text { 'behaviou } \\
\text { r' }\end{array}$ & 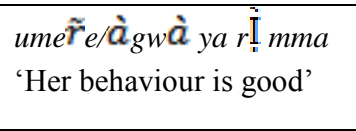 & 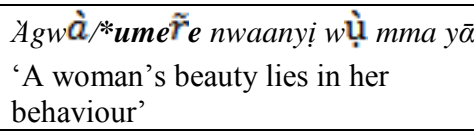 \\
\hline 41 & $\begin{array}{l}\text { ntìshì/ } \\
\text { ndụndu }\end{array}$ & 'shortness & $\begin{array}{l}\text { Di gi ri ntìshì/ndundu } \\
\text { 'Your husband is short' }\end{array}$ & $\begin{array}{l}\text { Oshishi } \text { i rị ntìshi/*ndundu } \\
\text { 'This stick is short' }\end{array}$ \\
\hline 42 & oyi/ugụ̀ rù̀ & 'coldness' & $\begin{array}{l}\text { Oyi/ugù̀ rù̀ tuga m } \\
\text { 'I am feeling cold' }\end{array}$ & $\begin{array}{l}\text { ugù̀ } r \text { प̆̀/*oyi afừ } l a \\
\text { 'Cold (harmattan) has started' }\end{array}$ \\
\hline 43 & $a v$ ù̀/ụ̀kwe & 'song' & 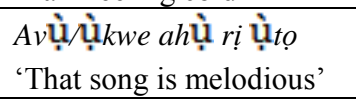 & 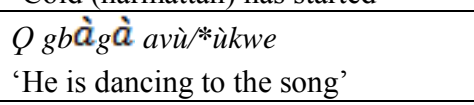 \\
\hline 44 & 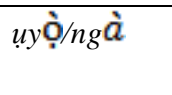 & $\begin{array}{l}\text { 'place of } \\
\text { abode' }\end{array}$ & $\begin{array}{l}O \text { bị } \grave{a}_{r} \grave{a} u y \underline{x} / n g \grave{a} \text { anyi } \\
\text { 'He came to our place' }\end{array}$ & $\begin{array}{l}\text { Njoku wù onye nga a/*uyọ̀ ọ̀ } \\
\text { 'Njoku is from this place' }\end{array}$ \\
\hline
\end{tabular}


If we look at the synonyms above, we can see that they differ in, at least, one context. That is to say that the synonymous lexemes cannot substitute one for another in all contexts. The above sets of synonyms, therefore, do not qualify as absolute synonyms in Owere-Igbo.

It should be noted also that in modern linguistics, meaning is studied by making a detailed analysis of the way lexemes and sentences are used in specific contexts. The importance of contextual effects, according to Ndimele (1999), was stressed by Wittgenstein 1889-1951 in his dictum: "the meaning of a word is its use in the language".

The interchangeability or substitution test which we have carried out above is a reliable test/method for determining absolute synonymy because it reveals at once whether and how far synonyms are interchangeable. For example, using this test we have shown above that the following pairs of synonyms, mèshie/gùshie 'close', ntìshì Indundu 'shortness', ma/sa 'wash', etc., are not absolute synonyms since they are not interchangeable in all sentence contexts. For instance, mèshie/gùshie 'close' are synonymous in one context, but gùshie could not substitute for mèshie in the other context. Similarly, ntìshì / ndundu 'shortness' are synonymous in one context, but ntìshì could not replace $n d u n d u$ in another context.

Cruse (1986:268) sees the substitution method as the best method of determining synonymy. Using this method, we have seen that the pairs of synonyms such as we have investigated are not interchangeable in all contexts since we have found, at least, one context for each in which one member of the pair may be used, but not the other member. The method is very insightful. As Lyons (1968:448) tersely puts it: "The condition of interchangeability in all contexts reflects the common assumption that words are never synonymous in any context unless they can occur (and have the same sense) in all contexts."

It is the contexts in which the synonymous lexemes occur that help in determining the differences between the synonyms. Hence, we are safe to conclude that the synonyms (in the sense of sameness of meaning) we have investigated are contextdependent or context-sensitive. These are so called because it is the linguistic context that gives a synonymous alternative. The synonyms so far examined are, therefore, not absolute synonyms in Owere Igbo. Our observation also confirms Cruse's (1986:2680 assertion that: "Lexemes would be absolute synonyms if and only their contextual relations were identical".

B. Connotative Differences: Another way of looking at the contextual influence on synonymy, which we also investigated, is by noting the connotative meaning of the synonyms. It is worth remarking that in semantics, there is a 
distinction between denotative and connotative levels of meaning. Denotative meaning is also referred to as logical, referential or ordinary meaning of lexemes ( Ndimele 1999:32). Connotative meaning, on the other hand, refers to other implications suggested by a lexeme apart from its ordinary meaning. In Owere-Igbo as in most other languages, it is difficult to find lexemes, which can replace each other in all contexts without a change in meaning because there are usually connotative differences.

An apparent pair of synonyms in Owere-Igbo may on close observation prove to have similar or identical denotation, but have different shades of meaning of association in their connotative sense. For example, àmàmiȟe and àko 'wisdom' could be said to be synonymous in Owere-Igbo, but àko has connotations of craftiness or trickiness which àmàmî̃̂̉e does not share. Similarly, àpàrì and ǹ̀zuzù 'foolishness' are synonymous in one of their senses, but àpàrì has the connotation of imbecility or utmost stupidity which ǹ̀zuzù does not have.

Connotation is based mainly on association with other facts such as emotions. The emotive association of words suggests the feeling which accompanies the fact. According to Ullmann (1962:130), “... any word even the most ordinary and prosaic may, in certain contexts, be surrounded by an emotive aura". The connotation a word acquires, however, depends on a number of factors. One such factor, according to native speakers, is common usage, i.e., the circumstance in which a lexeme is used may lead to a shift in the applicability of the lexeme. For instance, in certain contexts, the lexeme àko 'wisdom' would suggest 'craftiness' as in onye akō 'the crafty one'. In another context, the pejorative connotation may improve to assume a neutral or complimentary connotation as in inwè ako nà uchè 'to have wisdom'. Similarly, nwaànyì 'woman' in one context has the negative meaning 'frailty', but in another context can mean 'carefulness' or 'kindness'.

When there is such a shift in application, only one of the senses is normal, the rest have emotive undertones. Connotative meaning is, therefore, subject to interpretation and often influenced by the age, sex, education and culture of the speaker. It is so unstable that a change in social attitude or even a variation in attitudes between generations may make a considerable difference in the connotation.

C. Collocative Differences: Synonyms also differ in Owere-Igbo because one of the members may be collocatively restricted. Collocation refers to the habitual co-occurrence of individual lexical items Crystal (1997:62). In collocatively restricted synonyms, the rule of selectional restriction operates and determines 
what synonym occurs with what lexeme. For example, the synonyms mèshie/gùshie 'close' in Owere-Igbo, as we noted, differ only in respect of collocational restriction because gùshie occured only with the lexeme ùzo 'door'. *Gùshie akwukwo is, therefore, collocationally unacceptable because it violates the collocational restrictions of one of the synonyms. For example, in Owere-Igbo the idiomatic expression òke nà ngwèrè (literally rat + lizard) means 'everybody' and does not refer to rats and lizards. According to Bright and Mcgregor (1970:16), some collocations are totally predictable. In OwereIgbo, for instance, à ku 'possessions' collocates with ùba 'possession of assets' as in, àkù nà ùba 'wealth'; $\bar{q} f o ̣$ 'symbol of truth that is binding on all' collocates with ogù 'innocence' as in ōfọ na ogù to mean 'complete innocence'.

Collocations, however, are not to be confused with association of ideas because the way lexemes come together may have nothing to do with ideas. For example, the collocation $\bar{q} s a$ 'squirrel' and ùzè 'ground squirrel' as in the idiomatic expression $\bar{q} s a$ na ùzè meaning 'the whole people' has nothing to do with animals, but 'people' (i.e. human beings).

Some collocations, according to Saeed ( 2009), can become fixed expressions. For example, we talk of aka nri nà aka èkpè 'right hand and left hand' as used in the proverb, aka nrì kwoo aka ekpe, aka ekpe akwoo aka nri meaning 'reciprocity'. Colocations (fixed expressions) can also result in the creation of idioms which are "fixed group of words with special meanings different from the meanings of the separate words". Owere-Igbo idioms in some cases defy translation into good English (Emenanjo 1996:59).

Collocational searches are very important in uncovering idiomatic usages. But as Landau (2001:316) notes, the difficulty is in deciding whether a collocation is an idiom or not. Idioms involve collocation of a special kind. An idiom is like a single lexeme because the meaning of the entire expression is equivalent to the kind of meaning that a single lexeme has. Although the idiom is like a single lexeme, it does not function as one. Hence, the combination of lexemes in an idiom yields some meaning different from the basic meaning of its component parts. It is for this reason that idiomatic expressions are difficult to translate from one language to another.

In Owere-Igbo, a single lexeme can also have an idiom as its equivalent in a synonymous pair. It should be pointed out, however, that these lexemes are not synonyms in the sense of being interchangeable in all contexts; rather the idiomatic 
meanings (or expressions) are used figuratively. Examples of such idioms are shown on Table 3.

\section{Table 3: Idioms and their Synonymous Equivalents}

\begin{tabular}{|c|c|c|c|c|c|}
\hline $\mathbf{S} / \mathbf{N}$ & $\begin{array}{l}\text { Single } \\
\text { Lexeme }\end{array}$ & $\begin{array}{l}\text { Meaning of } \\
\text { Single Lexeme }\end{array}$ & Idiom & Literal Meaning & $\begin{array}{l}\text { Meaning of } \\
\text { Idiom }\end{array}$ \\
\hline 57 & Oshī & 'stealing' & $\begin{array}{l}\text { imē } a k a \\
\text { àbùọ }\end{array}$ & $\begin{array}{l}\text { 'to make use of two } \\
\text { hands' }\end{array}$ & 'stealing' \\
\hline 58 & njo & 'wickedness' & afo ịtā miri & $\begin{array}{l}\text { 'stomach that is dried } \\
\text { of water' }\end{array}$ & 'wickedness' \\
\hline 59 & Èberè & 'mercifulness' & $\begin{array}{l}\text { inwe afo } \\
\text { oma }\end{array}$ & $\begin{array}{l}\text { 'to have good } \\
\text { stomach' }\end{array}$ & 'mercifulness' \\
\hline 60 & arụ̀ & 'abomination' & ipū eze elū & $\begin{array}{l}\text { 'to grow the upper } \\
\text { teeth' }\end{array}$ & 'abomination' \\
\hline 61 & èkèle & 'greeting' & ịtā oji akāa & $\begin{array}{l}\text { 'to eat kolanut' with } \\
\text { hands' }\end{array}$ & 'greeting' \\
\hline 62 & $M m \bar{a}$ & 'beauty' & $\begin{array}{ll}a p \underline{u} & n^{\prime} \\
a n w \underline{̀} & \end{array}$ & $\begin{array}{l}\text { 'not exposed to the } \\
\text { sun' }\end{array}$ & 'beauty' \\
\hline 63 & Ishiikhē & 'stubbornness' & $\begin{array}{l}\text { igbā ishi } \\
\text { akwarāa }\end{array}$ & 'to harden one's head' & 'stubbornness' \\
\hline 64 & $u j \overline{\mathbf{Q}}$ & 'fear' & $\begin{array}{l}\text { obÌ iwùbhà } \\
\text { afọ }\end{array}$ & $\begin{array}{l}\text { 'heart jumping into } \\
\text { the stomach' }\end{array}$ & 'fear' \\
\hline 65 & $g \grave{a}_{r} \grave{a}_{g} \grave{a}_{r} \grave{a}$ & 'agility' & $\begin{array}{l}\text { okhu nà } \\
\text { miri }\end{array}$ & 'fire and water' & 'agility' \\
\hline 66 & $m m \grave{a} k w \grave{a}_{r} \grave{a}$ & 'regret' & $\begin{array}{ll}\text { it } \bar{a} & \text { ikikere } \\
e z \bar{e} & \end{array}$ & $\begin{array}{l}\text { 'to chew the molar } \\
\text { teeth' }\end{array}$ & 'regret' \\
\hline 67 & $a \widetilde{\mathrm{h}}_{u} \tilde{\mathrm{h}}_{u}$ & 'suffering' & $\begin{array}{l}\text { ijİ ezē kpee } \\
\text { eme } \tilde{\widetilde{r}}_{\bar{e}}\end{array}$ & $\begin{array}{l}\text { 'to use teeth in cutting } \\
\text { palm frond' }\end{array}$ & 'extreme' \\
\hline 68 & $n s o \widehat{\mathrm{h}}_{u r u}$ & 'respect' & $\begin{array}{l}\text { inwē } \\
\text { oma }\end{array}$ & 'to have good head' & 'respect' \\
\hline 69 & ikhe & 'difficulty' & $i t a \bar{a} a k p \underline{̀}$ & 'to crack hard nut' & 'difficulty' \\
\hline 70 & mkparì & ‘saucy' & $\begin{array}{l}\text { inwē } \quad \text { onu } \\
\text { ojoọ }\end{array}$ & 'to have bad mouth' & ‘saucy' \\
\hline 71 & ashì & 'falsehood' & $\begin{array}{l}\text { inwē } \\
a b \underline{u}_{o}\end{array}$ & 'to have two tongues' & 'falsehood' \\
\hline 72 & $n \operatorname{sog} b u$ & 'trouble' & $\begin{array}{l}\text { agwo inu } \\
\text { akirika }\end{array}$ & $\begin{array}{l}\text { 'snake to be in raffia } \\
\text { palm' }\end{array}$ & 'trouble' \\
\hline 73 & $\grave{a ̀}_{k w u n} \grave{a}$ & 'flirt' & $\begin{array}{l}\text { anya inu } \\
\text { ama }\end{array}$ & 'eyes to be outside' & 'flirt' \\
\hline
\end{tabular}


What we have done on Table 3 is to extend the definition of synonymy to cover relations existing between single lexical items and group of lexical items that are brought together in a particular syntagmatic construction, i.e. idioms. For example, the single item oshi 'stealing' and the idiom imē aka àbuo which literally means 'to do two hands', but idiomatically 'stealing', are synonymous.

It should be pointed out, however, that these are not synonyms in the sense of being interchangeable in all contexts; rather the idiomatic expressions are used in figurative language. No Owere-Igbo speaker would, for instance, use the idiom ijì eze kpee emere instead of ahuhu in ordinary speech, though both of them mean 'suffering', except in idiomatic usage.

Idioms ften have a stronger meaning than their non-idiomatic counterparts, i.e. synonyms. For example, afo ita miri 'wickedness' has more emphasis than njo 'wickedness', although they mean the same thing. Two or more idioms can also be synonymous as exemplified on Table 4:

Table 4: Synonymous Idioms

\begin{tabular}{|c|c|c|c|c|c|c|}
\hline $\mathbf{S} / \mathbf{N}$ & Idiom & Literal Meaning & $\begin{array}{l}\text { Meaning of } \\
\text { Idiom }\end{array}$ & Idiom & Literal Meaning & $\begin{array}{l}\text { Meaning of } \\
\text { Idiom }\end{array}$ \\
\hline 74 & ishi okpukpu & 'bony head' & 'stubbornness' & ishiike $\bar{e}$ & 'head head' & 'stubbornness' \\
\hline 75 & iruwe ishi & $\begin{array}{l}\text { 'to obey with } \\
\text { head' }\end{array}$ & 'respectfulness' & $\begin{array}{l}\text { inwē ishi } \\
\text { oma }\end{array}$ & $\begin{array}{l}\text { 'to have good } \\
\text { head' }\end{array}$ & 'respectfulness' \\
\hline 76 & 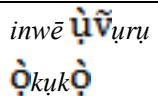 & $\begin{array}{l}\text { 'to have the brain } \\
\text { of a fowl' }\end{array}$ & 'dunce' & $\begin{array}{l}\text { ishi } \\
\text { mkposhi }\end{array}$ & 'blockhead' & 'dunce' \\
\hline 77 & aka ntut प্̀ & 'picking hand' & 'stealing' & $\begin{array}{l}i m \bar{e} a k a \\
\dot{\alpha} b u \overline{\bar{Q}}\end{array}$ & 'to do two hands' & 'stealing' \\
\hline 78 & irÌ $n g \grave{a}_{r i}$ & 'to eat bribe' & 'bribery' & imē aka $\bar{a} z u$ & 'to do back hands' & 'bribery' \\
\hline 79 & $i_{\bar{u}} \grave{a}_{l} \grave{a}$ & $\begin{array}{l}\text { 'to desecrate the } \\
\text { land' }\end{array}$ & 'abomination' & ipū eze elū & $\begin{array}{l}\text { 'to grow the upper } \\
\text { teeth' }\end{array}$ & 'abomination' \\
\hline 80 & aka ikhē & 'hardened hand' & 'stinginess' & aka akpì & 'tightened hand' & 'stinginess' \\
\hline 81 & imē mpu & $\begin{array}{l}\text { 'to do an } \\
\text { abominable act' }\end{array}$ & 'heinous crime' & $\begin{array}{l}i_{n y} \hat{a} \\
\hat{a}_{k p} \grave{a} \text { eli } \\
o z \bar{u}\end{array}$ & $\begin{array}{l}\text { 'to hang bag and } \\
\text { do burial' }\end{array}$ & 'heinous crime' \\
\hline
\end{tabular}

The examples on Table 4 show that two or more idioms can also be synonymous in Owere-Igbo. For instance, the idiom iruwe ishi 'respectfulness' is synonymous with the idiom inwe ishi oma 'respectfulness'.

We have so far discussed the different ways in which synonyms differ to ascertain whether absolute synonyms exist in Owere-Igbo. It is important to observe that these 
various methods have so far revealed that absolute synonyms do not exist in OwereIgbo.

To further achieve our purpose, the researcher interviewed the two groups of respondents chosen for this study. The first group is the Linguistically Trained Research Collaborators (LTRC), i.e. those who have formal training in linguistics, while the second group is the Linguistically Untrained Research Collaborators (LUTRC), i.e., competent speakers of Owere-Igbo who have no training in linguistics, to enable us answer Research Objective 3. The result of the interview is presented on Table 5 which shows responses following the test for absolute synonymy based on selected lexemes:

Table 5: Responses on the Absoluteness of Synonyms in Owere-Igbo

\begin{tabular}{|c|c|c|c|}
\hline $\begin{array}{l}\text { Question items } \\
\text { (Sets of Possible Absolute } \\
\text { Synonyms) }\end{array}$ & Respondents & Responses & $\begin{array}{l}\text { Percentage of } \\
\text { Responses }\end{array}$ \\
\hline \multirow{6}{*}{$\begin{array}{l}\text { Do the following sets of lexemes } \\
\text { mean exactly the same thing in all } \\
\text { contexts in Owere Igbo (i.e., are they } \\
\text { absolute synonyms)? } \\
\text { ishiikhē/ekwēekwe 'stubbornness' } \\
\text { ntìrì/oyl' 'dirtiness' } \\
\text { obioma/obìmeàlà 'kindness' } \\
\text { ochịchịri/ìtìrì 'darkness' } \\
\text { mùo/wùo 'jump' } \\
\text { manù niine/onye niine 'everybody' } \\
\text { tèe/hìo 'rub' } \\
\text { okì̀/agadì 'oldness' } \\
\text { ugwulobọ 'enmity' }\end{array}$} & \multirow{6}{*}{$\begin{array}{l}\text { (1) Linguistically } \\
\text { Trained Research } \\
\text { Collaborators = } 90 \\
\text { (II) Linguistically } \\
\text { Untrained Research } \\
\text { Collaborators = } 110\end{array}$} & $\begin{array}{l}\text { Yes }=25 \\
\text { No }=65\end{array}$ & $\begin{array}{l}12.5 \% \\
32.5 \%\end{array}$ \\
\hline & & Total 90 & $45 \%$ \\
\hline & & Yes $=50$ & $25 \%$ \\
\hline & & $\mathrm{No}=60$ & $30 \%$ \\
\hline & & Total 110 & $55 \%$ \\
\hline & & $\begin{array}{l}\text { Yes }=75 \\
\text { No. }=125\end{array}$ & $\begin{array}{l}37.5 \% \\
62.5 \%\end{array}$ \\
\hline \multicolumn{4}{|c|}{ Grand Total $=$} \\
\hline
\end{tabular}

From the analysis of percentage scores on Table 5, it can be seen that out of ninety (90) Linguistically Trained speakers who responded to the question of whether the synonyms under investigation are exact equivalents of each other, 25 representing $12.5 \%$ of the respondents said yes, while 65 representing $32.5 \%$ said no.

For the Linguistically Untrained Respondents, 50 representing 25\% responded positively, while 60 representing $30 \%$ responded negatively. A close observation of 
the percentage scores will show that there is a negligible difference between the two shades of opinion as the majority of the speakers represented by $62.5 \%$ disagree on the absoluteness of the lexemes above, while $37.5 \%$ agreed that the lexemes are absolute synonyms.

\section{Conclusion}

In this study, we have critically analyzed synonymy drawing examples from OwereIgbo. Using various tests such as substitution or interchangeability method, contrastive method and statistical method, we have been able to prove that in OwereIgbo, this linguistic phenomenon, 'absolute synonymy' does not exist and if, at all, it exists, it is extremely rare, at least, as a relation between lexemes in Owere-Igbo.

We draw this conclusion on the ground that an examination of all illustrative samples of possible candidates for absolute synonymy given by Owere-Igbo speakers reveals that none of the pairs investigated satisfied the criteria used. Based on the analysis, we feel safe to conclude that since the lexemes we tested cannot substitute for each other in all contexts because slight, but detectable differences are always invariably present, absolute synonyms do not exist in Owere-Igbo.

\section{References}

Cruse, D. A. (1986). Lexical semantics. Cambridge: Cambridge University Press.

Cruse, D. A. (1990). Language, meaning and sense: Semantics. In Collinge, N. E. (ed.). An encyclopedia of language. 156-159. London, New York: Routledge.

Crystal, D. (1995). The Cambridge encyclopedia of the English language. Cambridge: Cambridge University Press.

Crystal, David. (1997a). A dictionary of linguistics and phonetics, 4th Edition. Oxford: Blackwell.

Crystal, David. (1997b). The Cambridge encyclopedia of language, 2nd Edition. Cambridge: Cambridge University Press.

Emenanjo, E. N. (1996). Standard Igbo spelling: A practical guide. Aba: Unique Press Limited.

Emenanjo, E.N. (2001). Igbo or Igboid: Asụsu n’ agburu ndi Igbo. Owerri: Ahiajọkụ Lecture. 
Fromkin, V., \& R. Rodman (1998). An introduction to language, 6th Edition. New York: Harcourt Brace College Publishers.

Hurford, J. R. \& B. Heasley (1983). Semantics: A course book. Cambridge: Cambridge University Press.

Hyde, Faustina (1990). Learning vocabulary in a second language situation: Part 2 Approaches. A Paper Presented at the 19th West African Languages Congress. Legon: University of Ghana Language Centre.

Kenworthy, Joanne (1991). Language in action: An introduction to modern linguistics. London and New York: Longman.

Kreidler, C.W. (1998). Introducing English semantics. London and New York: Routledge.

Landau, Sidney I. (2001). Dictionaries: The art and craft of lexicography, 2nd Edition. UK: Cambridge University Press.

Lyons, J. (1977). Semantics. 2 vols. Cambridge: Cambridge University Press.

Lyons, J. (1981). Language, meaning and context. London: Fontana Collins.

Mowarin, M. (2009). Aspects of lexico-semantic processes in Nigerian Pidgin. Journal of the Linguistic Association of Nigeria. Vol. 12, Pp. 57-67.

Ndimele, O. M. (1999). Semantics and the frontiers of communication, 2nd Edition. Port Harcourt: University of Port Harcourt Press.

Ullmann, Stephen (1962). Semantics: An introduction to the science of meaning. USA: Basil Blackwell and Mott Ltd.

Urdang, Lawrence (ed.). (1979). Longman dictionary of English idioms. Harlow and London: Longman Group Limited.

Saeed, J. (2009). Semantics (3rd ed.). West Sussex: Wiley. 